\title{
The Pollution and Destruction of the Niger Delta Ecosystem in Nigeria: Who is to be blamed?
}

\author{
Tombari Bodo, PhD \\ Department of Geography and Natural Resource Management, \\ Faculty of Social Science, University of Uyo, \\ Uyo, Akwa Ibom State, Nigeria \\ Batombari Gbidum Gimah, PhD Student \\ Department of Environmental Adult Education, Faculty of \\ Education, Ignatius Ajuru University of Education, \\ Iwofe, Rivers State, Nigeria
}

\begin{abstract}
Petroleum exploration has brought a lot of revenue to the Nigerian government as most of the country's investments and expenditures depend on the profits from oil. However, the processes of petroleum exploitation over the years have resulted in the destruction of the Niger Delta ecosystem. Thus, this study aims to analyse the impact of pollution on the Niger Delta Ecosystem in Nigeria and identify persons responsible for the devastation. Consequently, published literatures, newspapers, stored recordings and other valuable materials on the Niger Delta region were reviewed extensively. The study revealed that the stakeholders (government, operating oil companies, and host community representatives) in the business of petroleum exploration have always denied their involvement in the pollution and destruction of the region, but the fact remains that the operating oil companies are responsible for the numerous spills from their rusty or outdated pipelines and the gases that are been flared in the region; the illegal refining and pipeline vandalism that are perpetrated by some members (militant groups) of the host communities have resulted in a more polluted environment; and government negligence in monitoring and supervising the oil operations in the region and ensure that polluted sites are adequately remediated had compounded the crisis and devastation in the region. All the stakeholders, in the business of petroleum exploration should accept responsibility of protecting the environment against further pollution by avoiding acts and practices that destroys the environment. In conclusion, the blame directly goes to the government, operating oil companies and the community representatives (militant groups, political
\end{abstract}


leaders, traditional ruler, and village chiefs), as culprits for the destruction of the Niger Delta ecosystem.

Keywords: Niger Delta region, oil exploration, destruction, devastation, petroleum, militancy, ecosystem

\section{Introduction}

The Niger Delta region in Nigeria is situated in the Gulf of Guinea between longitude $50^{\circ} \mathrm{E}$ to $80^{\circ} \mathrm{E}$ and latitudes $40^{\circ} \mathrm{N}$ to $60^{\circ} \mathrm{N}$ (see Figure 1) and it is the largest mangrove forests in Africa and the third largest in the world (Azaiki, 2003; Ana, 2011; Aniefiok, et al., 2013; Asanebi, 2016). The Niger Delta is classified under the tropical rain forest that is located in the north of the Delta (Aniefiok et al., 2013; Asanebi, 2016), which is located between $4^{0}$ $\mathrm{N}-10^{\circ} \mathrm{N}$ of the equator, with an altitude that is less than 1000 meters and a mean annual rainfall that is always high, and it is not the same within the region (Azaiki, 2003; Asanebi, 2016). The formation of the Niger Delta is as a result of the breaking away of the 4,100km-long Niger River connecting estuaries from where it flows into the Atlantic Ocean at the Gulf of Guinea (Fagbeja et al., 2008).The Niger Delta region is situated at the apex of the Gulf of Guinea on the west coast of Africa (Doust, 1999; Haach et al., 2000; Aniefiok, et al., 2013) and in the Nigeria's South-South geopolitical zone. The Niger Delta is a home to about 31 million people (Young, 2012; Aniefiok, et al., 2013), occupies a total area of about $75,000 \mathrm{~km}^{2}$ and which makes up $7.5 \%$ of Nigeria's land mass (Aniefiok, et al., 2013).

Historically, the Niger Delta region of Nigeria as identified by Sir Henry Willink's Commission that was set up by the British Government, saw Niger Delta region in 1958 to be represented by three major groups, which were -"Ogonis, Degema and Brass, including the western Ijaws" and this falls into Bayelsa, Delta and Rivers states (Asanebi, 2016). The findings of Sir Henry Willink's Commission about the region lead to the formation of the Niger Delta Basin Development Board (NDBDB) in 1961 by the first Republic Government of Nigeria (Asanebi, 2016). However, the geography of Niger Delta region has been redefined due to the politics involves in revenue distribution from the oil profits and with the aim of accessing bigger shares of the oil revenue (Asanebi, 2016). Consequently, President Olusegun Obasanjo's government included Akwa Ibom, Abia, Cross River, Imo, Ondo and Edo States to the core Niger Delta making it a total number of nine states in 2000 (Asanebi, 2016). 


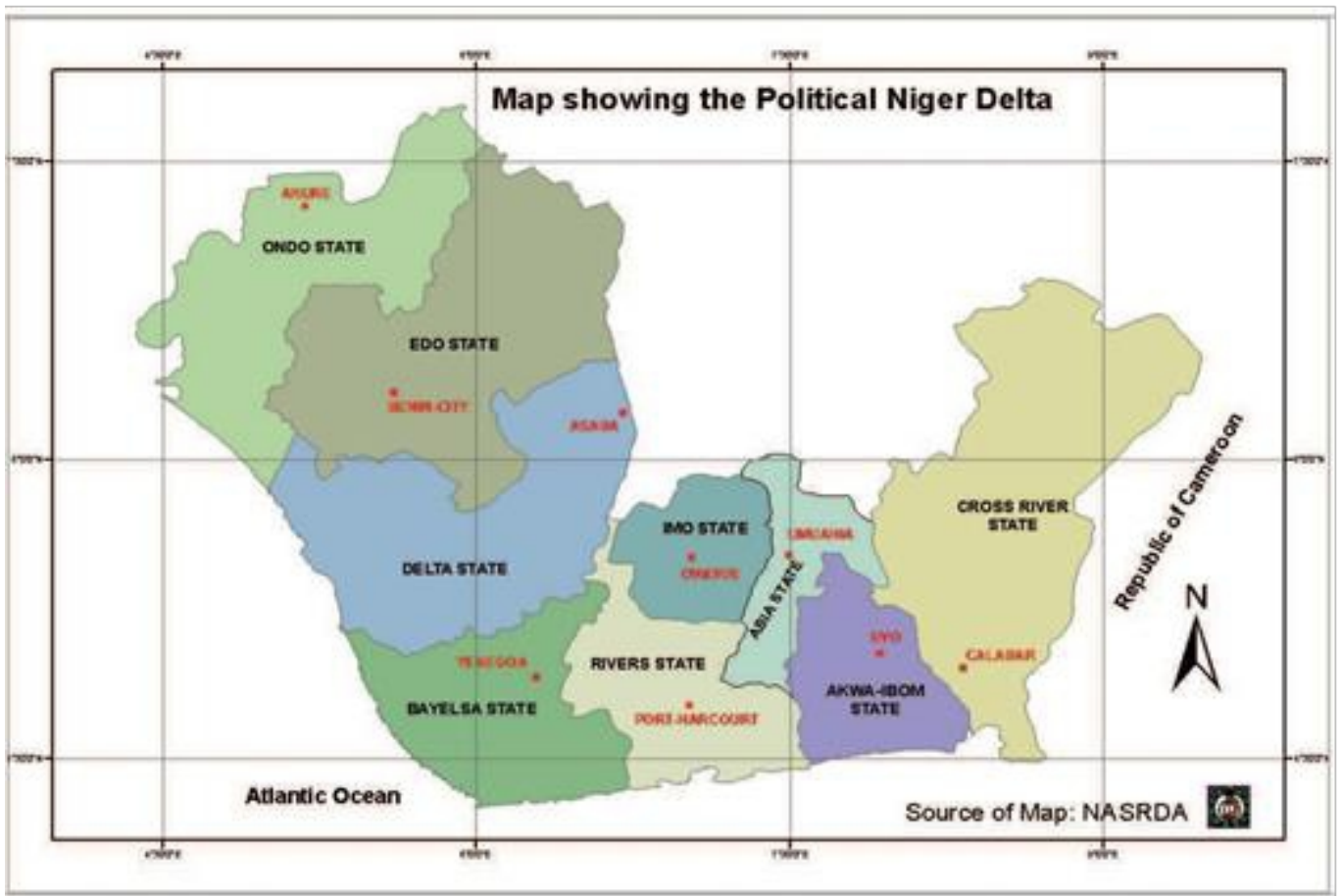

Figure 1: Map of the Niger Delta Region (Source: Ana, 2011)

Of these Niger Delta states, six of them, namely, Rivers, Akwa Ibom, Bayelsa, Cross River, Delta, and Edo States are further classified as southsouth zone of Nigeria (Asanebi, 2016). Some saw the major attractions behind this development as being political and economical, as it guarantees the states to enjoy the $13 \%$ derivation and other additional benefits from donors to the Niger Delta region, while politically it brings about togetherness for the ethnic minorities of southern Nigeria (Asanebi, 2016). Presently, the Niger Delta region is made up of 9 oil-producing states (Edo, Rivers, Abia, Akwa Ibom, Bayelsa, Cross River, Delta, Ondo and Imo) and 185 LGAs (Aniefiok et al., 2013). This region cuts across over 800 oil-producing communities with over 900 producing oil wells (Osuji and Onojake, 2004; Aniefiok, et al, 2019).

Since the discovery of petroleum in the Niger Delta region in 1958; the region has been a source of wealth to Nigeria as a country (Bodo, 2019) and Nigeria's oil and gas reserves have been estimated to be 35.9 billion barrels and 185 trillion cubic feet respectively, becoming the largest oil and gas reserves in Sub-Saharan Africa (Klett et al., 1997; Fegbeja et al., 2008). The government depends on the revenues accrues from oil for payment of all its liabilities and building assets for the nation (Bodo, 2018). In a nutshell, the oil industry is the pillar of Nigeria's economy, as it is responsible for 90 percent of the country's export revenues (Bodo and David, 2018). Oil resources have solidified Nigeria's position as the giant of Africa (Bodo, 2019). However, 
there had been grievances in many quarters that the other means of generating revenue in Nigeria has been abandoned since the discovery of petroleum (David, Bodo and Gimah, 2019). The region responsible for such wealth has been ecologically destroyed, with the locals suffering from abject poverty (Bodo and David, 2018). Subsequently, blames has been apportioned with every accused denying responsibility. This paper seeks to x-ray the extent of the ecological destruction of the Niger Delta; identify the victims and the culprits of the destruction; and the solutions to the challenges of the region.

\section{Impacts Of Petroleum On Nigeria's Economy}

Petroleum has continued to play a leading role in Nigeria and account for about 90 percent of Nigeria's gross earnings, 80 percent of the budgetary revenue, 95 percent foreign exchange earnings and contribute over 14 percent to the Gross Domestic Product as shown on Table 1 (Azaiki, 2007; Usman, Ikemefuna and Fatimah, 2015). Currently, Nigeria depends heavily on petroleum business for survival (Bodo and Ukpong, 2018). Nigeria was named by the International Monetary Fund as one of the fastest growing countries in the world with a growth of 9 percent in 2008 and 8.3 percent in 2009 (Onyemaechi, 2012; Usman et al., 2015). Using variables like Education, Gross Domestic Product, Employment opportunities, Foreign exchange reserves and Energy supply as yardstick for measuring the impact of petroleum on Nigeria's economy; one can conclude that petroleum is the mainstay of the economy (Abutu and Muhammad, 2013; Usman et al., 2015). The funds from the proceeds of petroleum resources have contributed immensely to the development and growth of so many sectors in Nigeria, especially the petroleum industry $(\mathrm{CBN}, 2011$; Usman et al., 2015). For instance, popular projects like Petroleum Development Trust Fund (PDTF), Education Trust Fund (ETF), and Tertiary Education Trust Fund (TETF) are funded from the revenues derived from petroleum exploitation (Usman et al., 2015). 
Table 1: Comparison between Oil and Non Oil Export in Nigeria from 1999 to 2015

\begin{tabular}{|l|l|l|c|}
\hline Year & $\begin{array}{l}\text { Oil (Billions in } \\
\text { Naira) }\end{array}$ & $\begin{array}{l}\text { Non-Oil (Billions } \\
\text { in Niara) }\end{array}$ & $\begin{array}{l}\text { Total (Billions } \\
\text { in Naira) }\end{array}$ \\
\hline 1999 & $1,169.50$ & 19.5 & $1,189.00$ \\
2000 & $1,920.90$ & 24.8 & $1,945.70$ \\
2001 & $1,839.90$ & 28 & $1,868.00$ \\
2002 & $1,649.40$ & 94.7 & $1,744.20$ \\
2003 & $2,993.10$ & 94.8 & $3,087.90$ \\
2004 & $4,489.50$ & 113.3 & $4,602.80$ \\
2005 & $7,140.60$ & 106 & $7,246.50$ \\
2006 & $7,191.10$ & 133.6 & $7,324.70$ \\
2007 & $8,110.50$ & 199.3 & $8,309.80$ \\
2008 & $9,861.80$ & 525.9 & $10,387.70$ \\
2009 & $8,105.50$ & 500.9 & $8,606.30$ \\
2010 & $11,300.50$ & 711 & $12,011.50$ \\
2011 & $14,323.20$ & 913.5 & $15,236.70$ \\
2012 & $14,260.00$ & 879.3 & $15,139.30$ \\
2013 & $14,131.80$ & $1,130.20$ & $15,262.00$ \\
2014 & $12,007.00$ & 953.5 & $12,960.50$ \\
2015 & $8,184.50$ & 660.7 & $8,845.20$ \\
\hline
\end{tabular}

Source: CBN Statistical Bulletin 2015

The oil industry has also benefited many Nigerians, as it has provided a lot of jobs for all categories of persons (highly skilled, semi skilled or unskilled) in the society (Usman, et al., 2015; Bodo, 2018). Today, multinational oil companies like Total, Shell, Mobil, Chevron, Agip etc are among the highest paying jobs in the country, with many youths clamouring to work in the oil sector (Odularu, 2008; Usman et al., 2015). The Nigerian government generate revenue from crude oil production through direct sales, which is operated by Nigeria National Petroleum Corporation (NNPC); Proleum Profit Tax paid by the oil companies; Royalties; Penalty for gas flaring and Rentals (NBS, 2011; Usman et al., 2015). The huge revenue realised from the oil business has provided the country with the opportunity for increased expenditure and investment (Akinlo, 2012).

Oil has made the name 'Nigeria' very popular among the countries of the world. Nigeria, aside from being the top 10 oil producers in the world and the $6^{\text {th }}$ largest exporter among the Organisation for petroleum Exporting countries (OPEC) members (Uwakonye, Osho and Anucha, 2006; Nwanze, 2007; Adewumi and Adenugba, 2010); the country has about 37.2 billion barrels in reserves which constitute about 3.1 percent of the global reserves 
(Gbadebo, 2008; Akinlo, 2012). Unfortunately, this overdependence has made government plans and intentions to be conditioned by the price of oil in the international market (Nwoba and Abah, 2017). In Nigeria, when the oil earnings increase, government usually expand their budgetary allocation and spending; and desperately seek a way out (like borrowing) when there is a fall in oil earnings ( Biodun, 2004; Abu and Chidi, 2012).

It is a fact that oil discovery brought a great wealth to Nigeria, as within 1971-2005, Nigeria has gained an estimated US\$390 billion in oil related fiscal revenue and was rated as the largest economy in Africa with a Gross Domestic Product of US\$522.6 billion as at 2013 as shown on Table 2 (Alley et al., 2014). This overdependence on oil has completely shut out Agriculture that was once the cornerstone of the country before the discovery of crude oil in commercial quantity in 1958 at Oloibiri (Aigbedion and Iyayi, 2007; Nwaba and Abah, 2017). However, many scholars share a different opinion on this subject matter, as they have reported that oil has increased sufferings and poverty of the people especially those at the source of origin of the oil (Bodo and Gimah, 2019).

Table 2:Comparison between Nigeria's Total Revenue from 1999 to 2015

\begin{tabular}{|l|c|c|l|}
\hline Year & $\begin{array}{l}\text { Oil Revenue } \\
\text { (Billions in Niara) }\end{array}$ & $\begin{array}{l}\text { Non Oil Revenue } \\
\text { (Billions in Naira) }\end{array}$ & $\begin{array}{l}\text { Total Revenue } \\
\text { (Billions in Naira) }\end{array}$ \\
\hline 1999 & 724.42 & 224.77 & 949.19 \\
2000 & $1,591.68$ & 314.48 & $1,906.16$ \\
2001 & $1,707.56$ & 903.46 & $2,231.60$ \\
2002 & $1,230.85$ & 500.99 & $1,731.84$ \\
2003 & $2,074.28$ & 500.82 & $2,575.10$ \\
2004 & $3,354.80$ & 565.70 & $3,920.50$ \\
2005 & $4,762.40$ & 785.10 & $5,547.50$ \\
2006 & $5,287.57$ & 677.54 & $5,965.10$ \\
2007 & $4,462.91$ & $1,264.60$ & $5,727.50$ \\
2008 & $6,530.60$ & $1,336.00$ & $7,866.59$ \\
2009 & $3,191.94$ & $1,652.65$ & $4,844.59$ \\
2010 & $5,396.09$ & $1,907.58$ & $7,303.67$ \\
2011 & $8,878.97$ & $2,237.88$ & $11,116.90$ \\
2012 & $8,025.97$ & $2,628.78$ & $10,654.75$ \\
2013 & $6,809.23$ & $2,950.56$ & $9,759.79$ \\
2014 & $6,793.82$ & $3,275.03$ & $10,068.85$ \\
2015 & $3,830.10$ & $3,082.41$ & $6,912.50$ \\
\hline
\end{tabular}

Source: CBN Statistical Bulletin 2015 
According to Campbell (2019), Nigeria is a poor country despite the availability of oil. In his article titled, "Nigeria is Oil Dependent, not Oil Rich”; while citing the math done by Dr. Salami, he compared the possible benefits that oil could bring to Nigeria with that of another oil producing nation, Saudi Arabia. He asserted that, "Nigeria could produce 800 million barrels of oil per year, which means that for every one of the Nigeria's roughly 200 million people, the country produces four barrels of oil. That meant four barrels of oil per year per Nigerian. At $\$ 45$ per barrel, that equates to about $\$ 180$ per person per year. Looking at Saudi Arabia, he estimated that it would produce 4 billion barrels each year, but with a population of only 30 million, the kingdom would produce \$6,000 for every one Saudi person, or over 130 barrels per person per year" (Campbell, 2019). The above assertion simply means that petroleum exploitation has not made Nigeria rich, but only provided a mean of revenue to the country.

The world has always seen Nigeria as a poor country with the standard of living of its citizens revealing a much impoverished country, despite a handful of few rich Nigerians (Campbell, 2019). The United Nations Human Development reported that between 2007-2008, 92.4\% of Nigerians lived below the income poverty line of $\$ 2$ a day (UNDP, 2007; Bodo, 2019); while in the Niger Delta region, $66.1 \%$ of the population self-classify themselves as poor (NBS, 2006; Fagbeja et al., 2008). Nigeria as a country was very rich before oil discovery as the revenue derived Agriculture was satisfactorily enough for everyone as the government never borrowed to meet their needs (Bodo, 2018). This eventuality, has made many to describe oil discovery in Nigeria as a curse and insisting that the country must diversify its economy if it is to break out of the poverty trap (Bodo and David, 2018; Agbaeze and Ukoha, 2018; Campbell, 2019). Despite the already economically sorry state of the people of the Niger Delta, they continue to suffer greatly from environmental pollution.

\section{Pollution And Ecological Destruction Of The Niger Delta}

Ecosystem is a community of living organisms that exist with the nonliving components of their environment that share the benefits in the environment such as air, food, water and soil (Hatcher, 1990). These biotic and abiotic components are connected together through nutrient cycles and energy flows (Odum, 1971). Humans operate within ecosystems and their cumulative effects are large enough to influence external factors like climate, as the ecosystems provide a variety of goods and services upon which people depend (Schoener, 2009). Human can pollute and destroy the ecosystem through the overuse of the available natural resources (Jones, Lawton \& Shachak, 1994). 
Pollution is simply the introduction of contaminants into the natural environment that could alter the normal occurrences or distort the orderliness in the system. Pollution was also defined by the European Union 1996 Council Directive on Integrated Pollution Prevention and Control (IPPC) as "the direct or indirect introduction as a result of human activity, of substances, vibrations, heat or noise into the air, water or land which may be harmful to human health or the quality of the environment, result in damage to material property, or impair or interfere with amenities and other legitimate uses of the environment" (Fagbeja et al., 2008). The pollution of the environment overtime usually leads to the total destruction of the entire ecosystem (Bodo, 2019). Ecological destruction is happening everyday as it is reported that $25 \%$ of our coral reefs have disappeared and it is expected that $60 \%$ more will be gone in 30 years (Gimah and Bodo, 2019a; Gimah and Bodo, 2019b) . This is as a result of acidification of the oceans through water pollution and illegal fishing. Quest for development has necessitated to intense deforestation leading to the burning and cutting down of more than 4.6 million hectares of forest (Bodo and Gimah, 2018; Gimah and Bodo, 2019a; Gimah and Bodo, $2019 b$ ). The case of Niger Delta ecosystem is even more pathetic as the people are not knowledgeable on the consequences and implications of destroying their environment (Bodo, 2018; Gimah and Bodo, 2019a) as oil exploitation has lead to massive habitat loss (Gimah and Bodo, 2019b).

\section{i) Air Pollution}

Air Pollution results from the presence of one or more contaminants or pollutants in the atmosphere in a quantity above the bearable limits over a long period of time causing harm to man, animals, plants and other materials exposed in the environment (Ukpere et al., 2018). Air pollution could come into a system through natural (earthquakes, volcanic eruption, etc) or anthropogenic or manmade sources (gas flaring, bush burning, etc). In the Niger Delta region, virtually all forms of pollution and the ecological destruction of the region are through manmade sources (Bodo, 2019).

Air pollution is now a normal occurrence and a serious environmental problem confronting the Niger Delta people. The air pollution of the region results from operations of oil industries that usually releases a barrage of substances like volatile organics, oxides of carbon, nitrogen, sulphur, particulate matter, heavy metals and other toxics at levels that exceed both the national and international standards (Ana, 2011). In the Niger Delta, the major source of the air pollution is gas flaring by the operating oil companies (Bodo, 2018). Gas flaring contributed an estimated 12.7 million metric tonnes of carbon in 2004 through $\mathrm{CO}^{2}$ emissions by the oil industries in the Niger Delta alone (Marland et al., 2007; Fagbeja et al., 2008). Nigeria is reported to have the highest record (19.79\%) of natural gas flaring globally and is responsible 
for about $46 \%$ of Africa's total gas flared per tonne of oil produced (Cedigaz, 2000; Ana, 2011). Currently, in the Niger Delta region, there are not less than 123 flaring sites, making Nigeria one of the highest emitter of green house gases in Africa (Uyigue and Agho, 2007; Ana, 2011). Many in the region have reported decrease in visibility due to various combustion activities by the operating oil companies that is releasing oxides of nitrogen and other lower fractions of hydrocarbons daily into the atmosphere; causing serious smog in the region (Ana, 2011).

The daily flaring of gas in the region has lead to the discharge of about 45.8 billion kilowatts of heat are into the atmosphere of the Niger-Delta from 1.8 billion cubic feet of gas everyday (Aaron, 2006; Ana 2011). At this flared sites, temperatures are reported to be as high as $1,600^{\circ} \mathrm{C}$ (Ogbuigwe, 1998). It is reported that even at an average distance of 48.8 metres from from the flared sites in Isoko in Delta State, the temperature was still as high as $400^{\circ} \mathrm{C}$ was recorded (Ogbuigwe, 1998; Ana 2011). In all cases of air pollution, it was discovered that the statutory standards and regulations guiding air pollution in Nigeria were not followed (Oluwole et al., 1996; Olobaniyi and Efe, 2007).

\section{ii) Water Pollution}

Water is very essential for human survival. The challenges associated with the available water could either of the following cases: 'too little water, too much water, and polluted water' (Adebola 2001; Nduka and Orisakwe, 2011). Niger Delta region of Nigeria is faced several environmental issues among which water contamination is predominant (Akpan and Ajayi, 2006; Raji \& Abejide, 2013) and even the available water is usually polluted because of environmental pollution and degradation of the area (Efe, 2001). Infact, access to safe drinking water is gradually reduced based on the activities from oil exploration and spills (Akpan and Ajayi, 2006; World Bank, 2008). Studies have revealed that there is a strong relationship between human activities and pollution of the environment (Jenkins et al. 1996).

In the case of the Niger Delta region, the oil exploitation in the region by multinational oil companies has lead to the water contamination of the entire region and has had its toll on the environment (Nduka et al. 2008). Oil extraction and spill as major contributors to extensive pollution of water sources in the Niger Delta (Akpan and Ajayi, 2006; UNEP, 2011; Bodo, 2019). In the Niger Delta alone, there have been more than 4,000 oil spills, discharging several million barrels of crude oil into the ponds, ditches, creeks, beaches, streams, and rivers (Amaize, 2007; Nduka and Orisakwe, 2011). Due to the release of large concentration of oxides of nitrogen and sulphur in the Niger Delta environment; some cases of acidified rain occur in the region (Saro-Wiwa, 1992, 1995; Ana, 2011). The presence of acidified rain water in the environment causes the corrosion of roofing sheets, monuments and other 
economic structures (Ana, 2011). A number of cases of water-borne illness are reported annually due to effect of oil spill-related water pollution (Ana, 2011; Nwilo \& Badejo 2015; David and Bodo, 2019; David, Bodo and Gimah, 2019).

\section{iii) Land Pollution}

Oil from the refineries is transported through pipelines that sometimes are already corroded or rusted (Ugboma, 2015). The leakages from the corroded pipes usually spurt over a wide area destroying crops, fish ponds, economic trees, farmlands, and biodiversity (Ugboma, 2015). It has been reported that an average of one oil spill occur every week causing grave damage in the environment in the Niger Delta (Federal Ministry of Environment, 2006; Ugboma, 2015). According to Ugboma (2015), fires occasioned by explosion of oil tankers, oil installations, and leakages from oil pipes and pipelines explosion during oil bunkering or pipeline vandalism destroys the plants, insects, birds and also burns the organic matter content of the soil. The resultant effects of land pollution lead to reduction agricultural activities, water supply settlement and the ecosystem or biodiversity within the region (Oronto, 1998).

The Oil spillage causes damages to the environment and suffering to the people as in many instances, lives have been lost (Ugboma, 2015). A typical example is in 1998 where more than 100 youths, women and children perished in the Jesse inferno leaving the community highly devastated and improvised; and the Idobo platform spillage that affected five communities leading to ecological damages of flora and fauna (Ugboma, 2015). Aside from the oil spillages; previous studies also revealed that flares have negative effects on vegetation growth, animal life and ecological equilibrium in the Niger Delta area (Alakpodia, 1989, 1995; Ana, 2011). The heating up of the environment from pollution sites kills vegetation around the heat area. It suppresses the growth of flowering plants and reduces agricultural productivity and wild life biodiversity (Ana, 2011). Obviously, Oil exploitation in the Niger Delta has lead to massive land degradation (SaroWiwa, 1992).

\section{Who Is To Be Blamed For The Destruction Of The Region? i) The Stakeholders}

The oil business in the Niger Delta region is very profitable to everyone involved (Bodo, 2019). The identified groups (or Stakeholders) that benefits from the oil exploitation business in Nigeria are the Government (comprising the Federal, State and Local Government); the operating oil companies (whether local or foreign); and finally the host community representatives, which are usually a political or local leader, paramount or 
village chiefs, or a militant leader or groups (Bodo and David, 2018). The government of Nigeria as we already know owns all the resources and the management of the oil business in Nigeria; and have been carrying out profitably for many years, as over 90 percent of its expenditures depend on the success of this business (Alley et al, 2014). The licensed operating companies are taxed with the responsibility of increasing production and sales of oil at all cost possible, and give expected returns to the government (Bodo, 2019). Unfortunately, for the government, these oil companies have expanded their operations and have been making profits even beyond the margin of bargain with the government, as it has been reported that the government oil owned company (NNPC) and some multinational oil companies do not give accurate reports on the number of barrels of crude oil produced per day or the amount sold in the international market (Bodo, 2019).

Some of the oil bearing community representatives seize the opportunity on being the spoke person to enrich themselves at the expense of developing the region. Monies meant for the development of the region are usually shared among themselves while the problem of the region persists (Bodo, 2019). In most cases these representatives return home to deceive or mislead the villagers and talk them into staying patiently with their suffering for a longer period. The Ogoni people were quick to identify some of their leaders that were collecting monies on their behalf, without using it for the development of the community, as they were called cultures. The militant youths on their own part terrorised the multinational companies through the kidnapping of their staffs, blowing up of their vessels and vandalism of oil pipelines; to draw the attention to their plight (Bodo and David, 2018). The government and the multinational have paid billions of naira to different militant leaders and groups as ransom for kidnap victims and also for them to surrender their arms and embrace peace. Currently, illegal oil bunkering or refining by the different militant groups in the region has lead to the enrichment of the operators with benefits shared with the security operatives on a daily basis.

For the stakeholders, oil exploitation has been very beneficial and should continue as long as they continue to be part of the booming business.

\section{ii) The Victims}

The Niger Delta has been described as a region that is so rich in petroleum resources and yet it is the home to one of the poorest groups in the country. In most of the communities that are host to the operating oil companies, there are no basic amenities like safe drinking water or electricity. The natural systems of air, water and land have been massively destroyed. The victims in the Niger Delta region are the ordinary community dwellers or villagers (constituting men, women and children) with no traditional or 
political title, and with little or no money to relocate from the polluted areas and with no alternative means of livelihood (aside from farming and fishing); but rather stay-put in their communities and survive with the consequences of the polluted environment. These victims have become helpless, homeless and hopeless in their situation.

\section{iii) The Culprits}

Every stakeholder in the oil business in the Niger Delta has overtime declares their innocence in the destruction of the region. The denial by every stakeholders in the oil business has always come as surprising since the destruction of the region were not through natural processes (like volcanic eruptions, tsunamis, earthquakes, etc); but through human activities. Unfortunately, despite denying responsibility for the destruction of the ecosystem in the region; there had been counter accusations between the stakeholders on who should be blamed in the crisis and devastation of the region (Bodo, 2019).

Shell Petroleum Development Corporation (SPDC) in their 2006 Annual report stated that the oil industry submitted a proposal to the Department of Petroleum Resources (DPR) for the air quality assessment in the Niger Delta, but the approval from the government agency came after five decades of oil exploration, and gas flaring, in the region (Fagbeja et al., 2008). Thus, SPDC blamed the government for delays in monitoring the air quality and other development projects in the region. At other times, the other multinationals oil operators have expressed dissatisfaction over government refusal to approve or allow them carryout host community projects. The multinational oil companies have also on many occasions ascribed the cases of oil spills to sabotage that are carried out by members of the host communities.

The host communities on their own part have always accused the different multinational oil companies in Nigeria for the destruction of their land; and blamed the government for neglecting them and failing to keep their promises of cleaning up the polluted areas in their surroundings. SPDC has been accused by the Ogoni people for over 50 years massive destruction of their environment without any tangible development (Bodo and David, 2018; Bodo, 2019); this devastation was confirmed during the environmental assessment of Ogoniland by United National Environmental Programme (UNEP) in 2011. Other operating oil multinationals (like Mobil Oil, Agip Oil Company, etc) have also been accused on several occasions, of destroying the environment by the host communities. The foreign multinational oil companies have been accused of flaring gases without any form of caution. According to Bodo (2019), Chevron in 1980 preferred to pay \$1 million per year as fine for gas flaring than incurring a cost of $\$ 56$ million in compliance 
with the Gas Re-injection Decree. Clearly, the operations of this multinational oil companies occasioned by several oil spills (see Table 3 ) in the environment has contributed to the destruction of the environment; so should be blamed for the part they have played.

Table 3: Quantity of Oil Produced and Spilled from 1991-1996.

\begin{tabular}{|c|c|c|c|c|c|c|}
\hline S/No & Year & $\begin{array}{l}\text { No. of } \\
\text { spill }\end{array}$ & $\begin{array}{c}\text { Quantity } \\
\text { spilled/barrel }\end{array}$ & $\begin{array}{l}\text { Quantity } \\
\text { recovered } \\
\text { (barrels) }\end{array}$ & $\begin{array}{l}\text { Net loss to } \\
\text { environment } \\
\text { (barrels) }\end{array}$ & $\begin{array}{c}\% \text { loss to } \\
\text { environment }\end{array}$ \\
\hline 1 & 1991 & 258 & $108,367.01$ & 2785.96 & $105,561.05$ & 97.43 \\
\hline 2 & 1992 & 378 & $1,476.70$ & $1,476.70$ & 49711.20 & 97.12 \\
\hline 3 & 1993 & 453 & 2937.08 & 2937.08 & $5,168.24$ & 63.76 \\
\hline 4 & 1994 & 495 & $2,3335.93$ & $2,3335.93$ & $32,796.78$ & 93.38 \\
\hline 5 & 1995 & 417 & 3110.02 & 3110.02 & 60567.15 & 95.12 \\
\hline 6 & 1996 & 156 & $1,183.80$ & $1,183.80$ & $38,719.86$ & 97.03 \\
\hline Total & & 2159 & $13,829.49$ & $13,829.49$ & $292,544.28$ & 95.49 \\
\hline
\end{tabular}

Source: Oronto, 1998; Ugboma, 2015.

Like the other oil companies operating in Nigeria, the UNEP in their report revealed that SPDC did not follow Nigeria environmental standard or even the SPDC industry standards (Amnesty International, 2014; Agbonifo, 2016). SPDC acknowledged the negligence of their operations in Ogoniland, when UNEP reported their discoveries on the Ogoni environment and promised to take immediate action, working with communities, government and other stakeholders to bring about the prosperity of the Ogonis (Agbonifo, 2016).

Table 4: Major Sources of Oil Spills in the Niger Delta (1998 - 2007)

\begin{tabular}{|l|l|l|l|l|}
\hline Year & $\begin{array}{l}\text { Equipment } \\
\text { Failure }\end{array}$ & Human Error & Sabotage/Theft & Total \\
\hline 1998 & 28 & 12 & 65 & 105 \\
\hline 1999 & 19 & 28 & 55 & 102 \\
\hline 2000 & 34 & 39 & 40 & 113 \\
\hline 2001 & 46 & 15 & 64 & 125 \\
\hline 2002 & 39 & 20 & 67 & 126 \\
\hline 2003 & 41 & 53 & 63 & 157 \\
\hline 2004 & 38 & 32 & 96 & 166 \\
\hline 2005 & 49 & 27 & 127 & 203 \\
\hline 2006 & 37 & 39 & 187 & 263 \\
\hline 2007 & 31 & 29 & 209 & 269 \\
\hline Percentage & $\mathbf{2 2 . 2 \%}$ & $\mathbf{1 8 . 1 \%}$ & $\mathbf{5 9 . 7 \%}$ & $\mathbf{1 0 0 \%}$ \\
\hline
\end{tabular}

Source: NNPC, 2013; Agbonifo, 2016)

Several literatures have reported that the activities of sabotage, theft, illegal bunkering and artisanal refining is the major source of oil spills (see 
Table 4) that is posing serious health and environmental disaster in the Niger Delta (NNPC, 2013; Agbonifo, 2016). The number of oil spills in Nigeria that occurs through sabotage and theft represents $59.7 \%$ of the total spills (NNPC, 2013). SPDC claimed that $75 \%$ of spills incidence recorded in 2009 to 2013 resulted from intentional third party interference with pipelines and other infrastructure (SPDC, 2014). SPDC has also revealed that $92 \%$ of all the volumes of spills from their facilities are from intentional damage and around 32,000 barrels of production per day were stolen from their pipelines and other facilities (SPDC, 2014). According to Obenade and Amangabara (2014), the Many of the scarcity and high cost of diesel, petrol and kerosene have been reported to be created by the demand for cheap supplies of locally refined fuels (Obenade and Amangabara, 2014). The local communities in the Niger Delta also share in the blame in the destruction of the Niger Delta's ecosystem as majority of the spilled (see Table 5) were due to sabotage (SPDC, 2014; Agbonifo, 2016).

Table 2: Oil spill, volume and cause (2005 - 2010)

\begin{tabular}{|c|l|l|l|}
\hline Year & No. of spills & Volume of spills/barrels & Major causes \\
\hline 2005 & 180 & 10,000 & 95\% sabotage \\
\hline 2006 & 170 & 20,000 & Sabotage and operational (50\% each) \\
\hline 2007 & 250 & 30,000 & Operational 70\% sabotage 30\% \\
\hline 2008 & 170 & 100,000 & Operational and sabotage 50\% each \\
\hline 2009 & 150 & 110,000 & Sabotage 90\% and operational 10\% \\
\hline 2010 & 190 & 28,000 & Sabotage $80 \%$ and operational $20 \%$ \\
\hline
\end{tabular}

Amnesty International (2011)

The government also share in the blame, because of the lack of appropriate regulation and the political will to enforce environmental regulations. Some have argued that government negligence of the challenges in the Niger Delta is the major cause of oil spills in the Niger Delta (Agbonifo, 2016). The government environmental agencies like, the Department of Petroleum Resources (DPR) and the National Oil Spill Detection and Response Agency (NOSDRA) lack the will power to respond to oil spills caused by the operating oil companies (Agbonifo, 2016). It is even reported in some quarters that these government agencies do not only receive information on incidences of oil spills from the multinational oil companies, but also depends on them for the financing of its operations as in many cases, the agencies have neither an helicopter nor a boat to monitor onshore and offshore oil and gas operations and spills (Odoemene, 2011). This situation has lead to the conclusion that the regulatory agencies are almost at the mercy of the operating oil companies and are fully dependant on them for logistical support (UNDP 2006; Muller 2010; Agbonifo, 2016). 


\section{Conclusion}

Oil exploration has lead to the massive environmental devastation of the Niger Delta region. The devastation of the region resulted to the lost of livelihood of the people as their farmlands and rivers for agricultural and fishing activities were destroyed. All stakeholders in the oil business cannot deny their involvement or the part they played in the destruction of the Niger Delta ecosystem. In fact, the blame directly goes to the government, multinational oil companies, militant groups, political leaders and the community chiefs for the destruction of the Niger Delta ecosystem.

The multinational oil companies should ensure they carry out their Corporate Social Responsibility (CSR) diligently by providing the needed basic amenities in the host communities and accepting responsibility for every oil spills in the region by ensuring that the oil pipelines are properly monitored or policed to ensure the safety of lives and properties in their line of operation. The members (the youths, political or local leaders, traditional leaders, chiefs, youths, women, etc) of the host communities should protect their environment against all forms of pollution by working in harmony with the operating oil companies, to create a peaceful atmosphere that is free from violence and any form of civil disturbance or civil unrest. The community members must avoid acts (like illegal oil refining, oil pipe vandalism, bombing of flow stations, kidnapping, etc) that further pollute their environment and put the image of member of the host community in a bad light. Rather, on a regular basis, a Memorandum of Understanding (MOU) between the host communities and the multinational oil companies should be reviewed.

The government (whether at the Federal or State or Local Government level) must regulate and monitor the activities of the multinational oil companies and that of the host communities in the Niger Delta region. The government must ensure that the Niger Delta is developed at all cost and all necessary environmental laws and regulations are followed in the exploration of petroleum in the region. The government and multinational oil companies must be seen to be fair and sincere to the plight of the Niger Delta people of Nigeria.

\section{References:}

1. Shell Petroleum Development Corporation, SPDC, People and the environment. Shell Nigeria Annual Report 2006. Shell Visual Media Services, London. 2006.

2. Saro-Wiwa K(1992). Genocide in Nigeria. The Ogoni Tragedy. London Lagos and Port Harcourt. Saros International Publishers.

3. Saro-Wiwa, K (1995). A Month and a Day; A Detention Diary. London Penguins. 
4. Efe, S.I (2001b) An appraisal of the quality of Rain and groundwater resources in Nigerian Cities. The case of Warri Metropolis. A Ph.D Seminar Paper Presented in the Dept of Geography and Regional Planning, Delta State University Abraka, pp 119.

5. Jenkins P, Southern T, Truesdale V, Jeary A (1996) Waters. In: Watts $\mathrm{S}$, Halliwell L (eds) Essential environmental science. Methods and techniques. Routledge, London, pp 336-350

6. Nduka JKC, Orisakwe OE, Ezenweke LO, Ezenwa TE, Chendo MN, Ezeabasili NG (2008) Acid rain phenomenon in Niger Delta region of Nigeria: economic, biodiversity and public health concern. Scientific World Journal 8:811-818

7. Raji, A. O. Y. \& T. S., Abejide, (2013). 'An Assessment of Environmental Problems associated with Oil pollution and gas flaring in the Niger Delta Region Nigeria (1960s-2000).' Arabian Journal of Business and Management Review, 3(3) p. 1. Available at: http://www.arabianjbmr.com/pdfs/OM_VOL_3_(3)/7 (Retrieved 12 June, 2019)

8. Nwilo, P. C. \& O. T., Badejo, (2005). 'Oil Spills Problem and Management in the Niger Delta,' International Oil Spills Conference Monitoring p. 2.

9. Marland, G., Boden, T. and Andres, R. J., (2007). Global, regional, and national CO2 emissions. Trends: A Compendium of Data on Global Change. Carbon Dioxide Information Analysis Centre, Oak Ridge National Laboratory, U.S.A. http://cdiac.ornl.gov/ftp/ndp030/nation.1751_2004.ems (Retrieved $10^{\text {th }}$ May, 2019).

10. Ana, G.R (2011). Air Pollution in the Niger Delta Area: Scope, Challenges and Remedies. https://www.intechopen.com/books/theimpact-of-air-pollution-on-health-economy-environment-andagricultural-sources/air-pollution-in-the-niger-delta-area-scopechallenges-and-remedies (Retrieved 15 June, 2019)

11. Adebola, K.D (2001). Groundwater quality in Ilorin Township: An Environmental Review. African Journal of Environmental Studies 2 $(2): 4-6$

12. Amaize, E (2007). Crises from the Creeks. Saturday vanguard newspapers (www.vangardngr.com). March 17. pp 11-13

13. Campbell, J (2019). Nigeria is Oil Dependent, not Oil Rich. Council on Foreign Relations. https://www.cfr.org/blog/nigeria-oil-dependentnot-oil-rich (Retrieved 11th June, 2019)

14. Agbaeze, E.K and Ukoha, K (2018). Oil a Blessing or a Curse: The Nigerian Experience. European Journal of Social Sciences, 56(3): 262-270 
15. Haack, R. C., P. Sundararaman, J. O. Diedjomahor, H. Xiao, N. J. Gant, E. D. May, and K. Kelsch, "Chapter 16: Niger Delta Petroleum Systems, Nigeria," Petroleum Systems of South Atlantic Margins: AAPG Memoir 73, M. R. Mello and B. J. Katz, eds., pp. 213231: American Association of Petroleum Geologists (AAPG), 2000.

16. Doust, H. (1990), "Petroleum geology of the Niger Delta," Geological Society, London, Special Publications, 50 (1). 365-365.

17. Young, E. M. M. (2012). Food and Development, Abingdon, Oxon: Routledge.

18. Osuji, L. C., and C. M. Onojake (2004), "Trace heavy metals associated with crude oil: A case study of Ebocha-8 oil-spillpolluted site in Niger Delta, Nigeria," Chemistry \& Biodiversity, 1 (11). 1708-1715.

19. Aniefiok E., Udo J., Margaret U., Sunday W. (2013). Petroleum Exploration and Production: Past and Present Environmental Issues in the Nigeria's Niger Delta. American Journal of Environmental Protection, 1(4): 78-90

20. Azaiki, S. (2003) Inequities in Nigerian Politics, Yenagoa: Treasure Communications Resource Limited.

21. Uwakonye, M.N; Osho, G.S and Anucha, H (2006). The Impact of Oil and Gas Production on the Nigerian Economy: A Rural Sector Econometric Model. International Business \& Economics Research Journal, 5(2): 61-75

22. Asanebi, D. H (2016). A Concise View of Niger Delta Region of Nigeria: An Interpretation of a Nigeria Historian. International Research Journal of Interdisciplinary \& Multidisciplinary Studies, 2(10): 56-63

23. Bodo T and David LK. (2018). The petroleum exploitation and pollution in Ogoni, Rivers State, Nigeria: The community perspective. European Scientific Journal. 14(32): 197- 212.

24. Akpan, D and Ajayi, O (2006). Adverse Effect of Water Contamination or Pollution to Human Health and Safety in the Nigeria Delta - Nigeria: An Environmental Case Study. Journal of Environment and Earth Science, 6(10): 91-94.

25. Nduka, J.K and Orisakwe, OE (2011). Water-quality issues in the Niger Delta of Nigeria: a look at heavy metal levels and some physicochemical properties. Environ Sci. Pollut. Res. 18:237-246

26. Bodo T. (2018). Community understanding of the environmental and socio-economic consequences of Petroleum Exploitation in Ogoni, Rivers State. International Journal of Advanced Research and Publications. 2(11):51-55. 
27. Bodo, T (2019). Deep Issues behind the Crisis in the Niger Delta Region: The Case of Oil Exploration in Ogoniland, Rivers State, Nigeria. Asian Journal of Geographical Research, 2(1):1-12.

28. David LK and Bodo T, Gimah B G (2019). Petroleum pollution and decrease neuroplasticity in brain development of the Ogoni children in Rivers State, Nigeria. Journal of Advances in Medicine and Medical Research 29: 1-13.

29. Gimah B.G and Bodo T (2019a) Creation of Awareness through Environmental Adult Education as a solution to the Problem of Habitat Loss in Ogoni, Rivers State, Nigeria. International Journal of Advanced Research and Publications. 3(1): 22-28.

30. Gimah, G.B and Bodo, T(2019b). Curbing human activities that degrade the environment: the relevance of environmental adult education. Earth \& Environmental Science Research \& Reviews. 2(5): 1-7

31. Bodo T, Ukpong IE (2018) Community Participation in the Remediation of Petroleum Impacted Sites in Ogoni, Rivers State, Nigeria. Multi-disciplinary Journal of Research and Development Perspectives 7: 97-104.

32. Usman A, Madu I, Abdullahi F (2015) Evidence of Petroleum Resources on Nigerian Economic Development (2000-2009). Business and Economics Journal, 6: 149. doi:10.4172/2151-6219.1000149

33. Azaiki, S. (2007) Oil, Gas and Life in Nigeria. Ibadan, Y-Books, a Division of Associated Book-Makers Nigeria Limited, Nigeria.

34. Onyemaechi, J.O (2012) Economic Implications of Petroleum Policies in Nigeria: An Overview. American International Journal of Contemporary Research 2: 60-71.

35. Akinlo, A.N (2012) How Important is Oil in Nigeria's Economic Growth. Journal of Sustainable Development 5: 165-179.

36. Abutu A, and Muhammad, H (2013). Challenges and Prospects of Nigeria's Oil Sector. Nigeria.

https://allafrica.com/stories/201303040649.html (Retrieved 16 March, 2013)

37. Odularu, G. O. (2008). Crude oil and the Nigerian economic performance. Oil and Gas Business. [Online] Available: http://www.ogbus.ru/eng (Retrieved 10th June, 2019)

38. Nwoba, M.O. E. And Abah, E. O. (2017). Impact of Crude Oil Revenue (COR) on Economic Growth in Nigeria (1960-2010). IOSR Journal of Humanities and Social Science. 22(7): 85-99

39. Abu, I. N. and Chidi, O. C. (2012). Deregulation and Privatisation of the Upstream and Downstream Oil and Gas Industry in Nigeria: Curse 
or Blessing? International Journal of Business Administration, 3(1), 26-50

40. Adewumi, F. and Adenugba, A. (2010). The State of Workers ${ }^{\text {ee Rights }}$ in Nigeria: An Examination of the Banking, Oil and Gas and the Telecommunication Sectors. Abuja.

41. Aigbedion and Iyayi (2007). Diversifying Nigeria"s Petroleum Industry. International Journal of Physical Sciences, 2(10), 263-270

42. Alley, I., Asekomeh, A., Mobolaji, H. and Adeniran, Y. (2014). Oil Price Shocks and Nigerian Economic Growth. European Scientific Journal, 10(19)

43. Biodun A. (2004). The Impact of Oil on Nigeriaes Economic Policy Formulation. A paper presented at the conference on Nigeria: Maximizing Pro-poor Growth: Regenerating the Socio-economic Database by Overseas Development Institute in collaboration with the Nigerian Economic Summit Group, 16th $/ 17^{\text {th }}$ June.

44. Gbadebo, O. O. (2008). Crude Oil and the Nigerian Economic Performance. http://www.ogbus.com/article/crude-oil-and-thenigerian-economic-performance/Retrieved on the 10th of June, 2019)

45. Nwanze, K. O. (2007). The Nigerian Petroleum Downstream Sector and Product Pricing: Issues and the Way Forward, Nigerian Economic Summit Group (NESG).

46. Central Bank of Nigeria (2011) Statistical Bulletin, Abuja, Nigeria.

47. Central Bank of Nigeria (2011) Statistical Bulletin, Abuja, Nigeria.

48. National Bureau of Statistics (2011), Nigeria.

49. Federal Ministry of Environment (1999). National Policy on Environment in Nigeria.

50. National Bureau of Statistics, (NBS), The Nigerian statistical fact sheets on economic and social development. National Bureau of Statistics, Abuja. 2006.

51. United Nations Development Programme (UNDP), UNDP human development report 2007/2008 - Fighting climate change: human solidarity in a divided world. UNDP, New York. 2007. Online. http://hdr.undp.org/media/hdr_20072008_en_complete_pdf (Retrieved 20 June, 2019).

52. Klett, T.R., Ahlbrandt, T.S., Schmoker, J.W., and Dolton, J.L., (1997) Ranking ofthe world's oil and gas provinces by known petroleum volumes. U.S.Geological Survey Open-file Report-97-463.

53. Fagbeja, M.A; Chatterton1, T.J; and Longhurst, J.W.S; Akinyede J.O \& Adegoke, J.O (2008). Air pollution and management in the Niger Delta - emerging issues. WIT Transactions on Ecology and the Environment, Vol 116, WIT Press. 
54. Aaron, K. K. (2006). Human Rights Violation and Environmental Degradation in the Niger- Delta in Elizabeth Porter and Baden Offord(eds), Activating Human Rights, Oxford, Barne, New York.

55. Cedigaz, (2000) www.cedigaz.org.Central Bank of Nigeria. (2004), Statistical Bulletin 15

56. Olobaniyi, S.B and Efe, S.I. (2007), Comparative assessment of rainwater and groundwater quality in an oil producing area of Nigeria: environmental and health implications, Journal of Environmental Health and Res. (6)2: 111-118.

57. Oluwole, A.F.; Olaniyi, H.B.; Akeredolu, F.A.; Ogunsola, O.J.; Obioh, I.B. (1996), Impact of the Petroleum Industry on Air Quality in Nigeria, Presented at the 8th Biennial International Seminar on the Petroleum Industry and the Nigerian Environment, Port Harcourt, 1721 November.

58. Ogbuigwe, A (1998), "Judicial Activism in the Enforcement of Environmental Regulations in the Petroleum Industry: Past, Present and the Future." Proceedings of 1998 International Conference on the Petroleum and the Nigerian Environment 83-123.

59. Uyigue, E. and Agho, M. (2007). Coping with Climate Change and Environmental Degradation in the Niger-Delta of South Nigeria. Benin. Community Research and Development Centre (CREDC).

60. Ukpere, D.R.T. ; Clifford, A.B.; Ojule, E.S.C. \& Ottah, C. R (2018). Impacts of Air Pollution in the Niger Delta Region of Nigeria. International Journal of Geography and Environmental Management, 4(4): 13-21

61. Bodo, T and Gimah, B.G (2018). Government Programmes in checking the occurrence of habitat loss and their implications for maintaining sustainable environment in Ogoni, Rivers State, Nigeria. European Journal of Biomedical and Pharmaceutical Sciences.5(12): 64-71

62. David LK, Bodo T. (2019).Environmental pollution and health challenges of the Ogoni People, Rivers State, Nigeria. International Journal of Advanced Research and Publication. 3(2):2832.

63. UNEP. Environmental Assessment of Ogoniland. Nairobi, Kenya: United Nations

EnvironmentProgramme;2011Available:http://postconflict.unep.ch/p ublications/OEA/UNEP_OEA.pdf (Retrieved on 30th June, 2019)

64. David, L., Bodo, T., \& Gimah, B. (2019). Petroleum Pollution and Decrease Neuroplasticity in Brain Development of the Ogoni Children in Rivers State, Nigeria. Journal of Advances in Medicine and 
Medical Research, 29(11)

$1-13$. https://doi.org/10.9734/jammr/2019/v29i1130141.

65. Alakpodia, I. J. (1989), The Effects of Gas Flaring on the Microclimate and Adjacent Vegetation in Isoko Area of Bendel State" (Unpublished M.Sc Thesis, University of Ibadan).

66. Alakpodia, I. J. (1995), "The Oil Industry and the Economic Environment of the Niger Delta"Paper presented at the 30th Annual Conference. Nigeria Geographical Association, at the University of Benin. Benin City. Nigeria.

67. Oronto, D. (1998) Geography and the Nigerian Environment. Geographical Perspective of Physical Environment.

68. Shell (2014): Oil Theft, Sabotage and Spills. Publication of Shell Companies in Nigeria, April 2014. Available online at http://s05.staticshell.com/content/dam/shellnew/local/country/nga/ downloads/pdf/2014bnotes/spills.pdf (Retrieved on the $10^{\text {th }}$ of December, 2018)

69. NNPC (2013): NNPC Annual Statistical Bulletin: Retrieved online at

http://www.nnpcgroup.com/PublicRelations/OilandGasStatistics/A nnualStatisticsBullet in.aspx (accessed July 2014).

70. Obenade, M. and Amangabara, G. T. (2014): The Socioeconomic Implications of Oil Theft and Artisanal Refining in the Niger Delta Region of Nigeria. International Journal of Science and Research (IJSR), 3 (7): $2390-2394$.

71. Odoemene, A. (2011): Social Consequences of Environmental Change in the Niger Delta of Nigeria. Journal of Sustainable Development, 4 (2), pp. 123 - 130.

72. Amnesty International (2014): No Progress. An Evaluation of the Implementation of UNEP's Environmental Assessment of Ogoniland, Three Years on. Available online at http://reliefweb.int/report/nigeria/no-progress-evaluationimplementation-unep-s- environmental-assessment-ogonilandthree (Retrieved on February 16, 2019)

73. Muller M. (2010): Revenue Transparency to Mitigate the Resource Curse in the Niger Delta: Potential and Reality of NEITI. Bonn: Bon International Center for Conversion (BICC), pp. $9-35$.

74. UNDP (2006): Niger Delta Human Development Report, Abuja, pp. 35-90

75. Hatcher, B. G (1990). "Coral reef primary productivity. A hierarchy of pattern and process". Trends in Ecology and Evolution. 5 (5): 149-155.

76. Odum, E. P (1971). Fundamentals of Ecology (third Ed.). New York: Saunders. 
77. Schoener, T. W. (2009). "Ecological Niche". In S. A. Levin (ed.). The Princeton Guide to Ecology. Princeton: Princeton University Press. pp. 2-13.

78. Jones, C. G.; Lawton, J. H.; Shachak, M. (1994). "Organisms as Ecosystem Engineers". Oikos. 69 (3): 373-386. doi:10.2307/3545850

79. Bodo, T and Gimah, B.G (2019). Oil Crisis in the Niger Delta Region of Nigeria: Genesis and Extent. European Scientific Journal, 15 (36): 141-158. 